\title{
Credit Behaviors of Rural Households in the Perspective of Complex Social Networks
}

\author{
Qiang Zhao, Yue Shen (iD, and Chaoqian Li \\ School of Economics and Finance, Xi'an Jiaotong University, Xi'an710064, China \\ Correspondence should be addressed to Yue Shen; 154271416@qq.com
}

Received 29 March 2021; Revised 5 May 2021; Accepted 25 May 2021; Published 4 June 2021

Academic Editor: Fei Xiong

Copyright ( 2021 Qiang Zhao et al. This is an open access article distributed under the Creative Commons Attribution License, which permits unrestricted use, distribution, and reproduction in any medium, provided the original work is properly cited.

\begin{abstract}
With the increasing number of social networks emerging and evolving, the influence of social networks on human behavior is now again a subject of discussion in academe. Dynamics in social networks, such as opinion formation and information sharing, are restricting or proliferating members' behavior on social networks, while new social network dynamics are created by interpersonal contacts and interactions. Based on this and against the backdrop of unfavourable rural credit development, this article uses CHFS data to discuss the whole and heterogeneous impact of social networks on rural household credit behavior. The results show that (1) social networks can effectively promote rural household credit behavior; (2) social networks have a significant positive impact on both formal credit and informal credit, but the influence of the latter is stronger; (3) both emotional networks and instrumental networks have a positive impact on formal credit and informal credit, and their influences are stronger on informal credit; (4) the influence of emotional network is stronger than instrumental networks on either formal credit or informal credit.
\end{abstract}

\section{Introduction}

For the past sixteen years, the documents of the Central Committee of the Communist Party of China (CPC) have been focused on the issue of "agriculture, rural areas and farmers." From promoting supply-side structural reform in agriculture to combating poverty and implementing the strategy of rural revitalization, rural financial reform is always involved. With the state attaching great importance to the priority development of agriculture and rural areas, China has initially formed a multisubject and multilevel rural financial service system, including policy-oriented, commercial financial institutions, formal finance with Rural Credit Cooperatives as the main body, and informal finance with private lending, pawnshops, and loan companies as the main body. China's rural financial system has been growing and improving. However, at the same time, rural households face financial constraints both in their daily lives and in agricultural production; their funds are in great demand [1]. According to the China Rural Financial Services Report, the balance of rural household loans stood at 10.34 trillion yuan at the end of 2019 , up $12.1 \%$ year on year but down $1.8 \%$ from the end of last year. Among these, borrowing from relatives and friends remains the main solution, with a high proportion of $68.3 \%$, compared with $24.4 \%$ from formal financial institutions. From the attitude of rural households to loans, $73.8 \%$ had no willingness to use credit and insisted on doing things according to the money they had on hand. Another $12.7 \%$ of rural households only consider loans for agricultural operations, while $9.2 \%$ consider loans for both household and agricultural operations. From the above data, the attitude towards credit use for rural households in China is still refusal and rejection; even if it is necessary, rural households prefer to borrow money from relatives and friends.

Why is this happening? On the one hand, rural land is owned by collectives while rural households have lower economic level, fewer household assets, and lack of corresponding collateral in the formal credit market [2], coupled with weak awareness of rural household credit, which cause serious information asymmetry between rural households and formal financial institutions, leading to adverse selection, moral hazard, and so on [3]. These above make rural households subject to more serious formal credit 
constraints. On the other hand, China has always attached great importance to "human relations," which are a typical relationship-oriented group. In social networks, if one party is short of funds, the first choice is to borrow money from his relatives and friends and the other is often the willingness to borrow money free because of "human relations" [4]. In addition, in rural areas, social networks not only can reflect a person's relationships but also, to some extent, can be used as a symbol of their credit and asset levels [5]. Social networks refer to "a relatively stable association system formed between social individuals because of interaction," which can be used as an indicator to measure the level of rural family "relationship" [4]. Using social networks of rural households can not only reflect the strength of informal credit but also alleviate the problem of information asymmetry between rural households and financial institutions to reduce the moral hazard and adverse selection of rural households [5]. The reasons are the stronger the social networks, the greater the reputation loss when breaking the contract, in return reducing social networks' strength and making the cost of breaking the contract higher [6]; besides, rural households in the same social networks can improve each other's loan repayment ability and credit standing [7].

In recent years, scholars have made an extensive and deep analysis on the problem of rural household credit in China and made theoretical and empirical analysis on the basic characteristics, influencing factors, and economic effects. Most works of literature on social networks and rural household credit thought that social networks have a significant role in promoting rural household credit behavior. Yang et al. discussed the relationship between social networks and farmers' private credit demand behavior and pointed out that social networks increased farmers' private credit demand and further promoted farmers' private credit behavior [1]. $\mathrm{Hu}$ and Chen focused on farmers' lending behavior and found that the tighter social networks are, the more lending behavior farmers would take [2]. Shoji et al., based on the data of Sri Lanka, deeply discussed the relationship between social capital formation and credit access and concluded that the quicker the social network formed, the easier the credit access [8]. Zhou analyzed whether the number of brothers of householders would affect families' saving rate in the financial market, and the research revealed householders with more brothers had a higher saving rate for they prepared to help each other; this meant more relatives would decrease the possibility of householders to use credit [9]. Many scholars have broadened their research perspectives on the strength and weakness of social network relationships [10], the structure of social capital [11], and the quality of social capital [12] and obtained different conclusions. Therefore, with the situation of previous researches, we found that though contents in previous research are extensive, neither the theoretical level nor the empirical level has been able to draw a consistent conclusion on the specific role of social networks on rural household credit behavior $[12,13]$, some research conclusions were contradictory $[7,8]$, and some studies that found the relationship and degree of social networks on rural household credit behavior were heterogeneous [10-12]. Thus, further research is necessary.

Considering the importance of social networks for rural economic development and the increasing formal credit demand, easing credit constraints, and raising the viability of formal credit institutions, this article studies the influence of social networks on rural household credit behavior based on social network theory, including the influence on formal credit behavior and informal credit behavior. What is more, it discusses the influence from emotional and instrumental heterogeneous perspectives. From theoretical and empirical analysis, we expect to explain the question of whether social networks can promote rural household credit behavior and how the relationship varies under the heterogeneous situation, finally expand China's rural financial system, and improve the availability of rural household financial services to give targeted policy recommendations and satisfy the credit needs of rural households.

\section{Theoretical Analysis and Hypothesis}

2.1. Mechanism of Social Network on Rural Household Credit Behavior. For debtors, there are usually two levels of decision-making in their lending behavior: the first level is whether to borrow and the second level is whether to keep the contract, as shown in Figure 1. Among them, the return of households that do not borrow is zero, while the return of keeping contract after borrowing is $R_{1}$ and the return of breaching contract after borrowing is $R_{2}$.

Usually, the decision tree is analyzed from far to near, so we first use the game method to judge the second-level decision (whether to keep the contract or not). Social networks have punishment mechanisms and reputation incentive effects [9]. When rural households borrow money and sign a contract, social networks would use the reputation mechanism to regulate and restrain it. If debtors violate the terms of the contract, they would be regarded as dishonest and ungrateful, making the debtors fall under psychological pressure and moral condemnation, thus encouraging the debtors to take the contract seriously. From the perspective of game theory, there is often a prisoner's dilemma between debtors and creditors, which leads to credit constraints. Meanwhile, social networks can use their own punishment mechanism and reputation incentives; thus, the prisoner's dilemma game with finite duration is transformed into a repeated game with an infinite duration. In fact, the rural household credit behavior is often conducted many times; both debtors and creditors need to enter the market repeatedly and deal with different opponents, so the game behavior of rural household credit undoubtedly has the repeated game characteristic of the infinite boundary.

Firstly, we assume that the rural household credit behavior is an infinite repeated game; secondly, there is a penalty mechanism in social networks, which can prevent the participants from defaulting easily; finally, we assume that the returns of both debtors and creditors are observable. The return on rural household credit is shown in Table 1, where $b<a$. The bottom right of the table is a game equilibrium formed by the rational behavior of both debtors and 


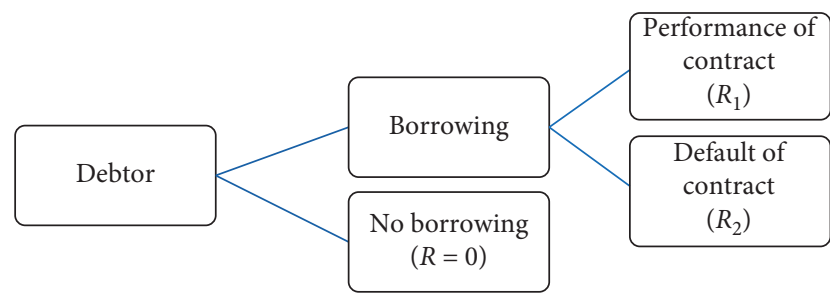

Figure 1: Decision tree of rural household credit behavior.

TABLE 1: Game strategy and benefits of participants.

\begin{tabular}{cccc}
\hline & \multicolumn{2}{c}{ Creditor } \\
& & Formal debt & Informal debt \\
\hline \multirow{2}{*}{ Debtor } & Breach of contract & $(-c, 0)$ & $(a-c, 0)$ \\
& Performance of contract & $(0, a)$ & $(b, b)$ \\
\hline
\end{tabular}

creditors, both sides benefit from $b$, but it is not stable. The upper left is in the formal credit situation; if debtors choose to default, due to the existence of social networks' punishment mechanism, debtors will have a loss of $c$ unit, including reputation loss or financial loss, and creditors will suffer a loss due to the debtors' default behavior, the return is zero or even negative; if debtors perform, creditors get $a$ unit of return. In informal credit, if debtors violate, they will get $a$ unit of revenue but also pay $c$ unit of social network penalty cost and creditors' revenue will be zero.

Because we assume the game behavior of rural households is an infinite repeated game, the total income of both sides is the discounted sum of the income in each period; that is,

$$
R_{i}=\frac{1-\delta}{1-\delta^{t+1}} \sum_{t=0}^{\infty} \delta r_{i}\left(\theta_{t}\right)
$$

where $R_{i}$ is the total income of debtors and creditors and $\delta$ is the discount factor, $0 \leq \delta \leq 1$, and $r_{i}\left(\theta_{t}\right)$ is the income of debtors and creditors in $t$ period. At this point, we analyze debtors' behavior. If debtors refuse to default, the total return is

$$
R_{1}=(1-\delta)\left(b+b \delta+b \delta^{2}+\cdots+b \delta^{t}+\cdots\right) .
$$

The limit of equation (2) is $b$. On the other hand, if debtors always default in the $t$ period, then total return is

$$
R_{2}=(1-\delta)\left(b+b \delta+b \delta^{2}+\cdots+b \delta^{t-1}+a \delta^{t}-2 c \delta^{t}+a \delta^{t+1}-2 c \delta^{t+1}+\cdots\right)
$$

Simplifying equation (3) and calculating limit, we get

$$
R_{2}=b-\delta^{t}(2 \delta-2 c-b) .
$$

Debtors choose to keep the contract only when $R_{1}>R_{2}$, which means

$$
\delta>c+\frac{b}{2}
$$

If the discount factor is understood as the patience of the players in the game [1], equation (5) shows that the degree of punishment $c$ can increase the discount factor and the debtors' patience and make them confident in their potential future earnings, thus reducing the incentive to default. That is, the greater the social networks penalty, the greater the debtors' patience and the smaller the incentive to default. Generally, the richer the social networks, the faster and farther the information transfer and the greater the penalties. Therefore, social networks help to promote rural household compliance behavior. In the second level of decision-making, households with stronger social networks are more likely to choose to keep the contract.

Furthermore, we make the first-level decision (whether to borrow or not). Rural households will choose to perform under the influence of a sufficiently large social network, which means $R_{1}>R_{2}$ and $R_{1}=b>0$. Under this circumstance, as opposed to not borrowing and no earning, rural households will choose to borrow. That is, the stronger the social networks are, the more likely the rural households are to borrow and the more likely they are to repay.
2.2. Theoretical Analysis and Hypothesis of Social Network on Rural Household Credit Behavior. According to the credit rationing theory, debtors must have enough assets to obtain a loan [14]. Rural household credit behavior is affected by two factors: on the one hand, rural household own capital is low or not, which makes it difficult to obtain loans, whether formal or informal. On the other hand, since the main source of income for rural households is work or agricultural management, work is vulnerable to the impact of farmers' own health, climate [15], etc. and agricultural production is vulnerable to climate and natural disasters and is inherently high-risk [16], so rural households do not have easy access to finance. As a traditional "hidden guarantee mechanism," social networks can be used as a "guarantee" for rural households with little or no free capital, which makes it easier to obtain financial credit [17]. In both formal and informal credit, members of a social network can measure each other's free capital and the marginal productivity of the debtors' efforts, as they interact closely with each other; thus, the cost of supervision is low and the supervision is powerful [18]. In addition, the sharing function of social networks can also increase household access to financial information, reduce the information asymmetry of their credit behavior, and further promote their credit behavior [9]. In terms of both credit rationing theory and information asymmetry theory, the more socially networked rural households are, the more active they are in crediting and the more likely they are to be financially supported [1]. Therefore, we propose Hypothesis 1. 
Hypothesis 1. Social networks can effectively promote rural household credit behavior.

Most previous studies consistently show that social capital is beneficial to easing rural household credit constraints and improving the availability of rural household credit $[1,15,16]$. Social network, as an implicit guarantee mechanism, can fill the gap when rural families carry out formal credit. For example, credit cooperatives do not need collateral and require borrowers to provide group guarantee. Generally, five to seven people form a mutual guarantee group, and the members are responsible for the liabilities of other people in the group. If someone in the group defaults on the loan, the other people in the same group will not be able to obtain new loans. However, at the same time, there is still a gap between this way of guarantee and the real material guarantee, and rural families may still be constrained by formal credit rationing $[18,19]$. For this reason, rural households often choose to obtain funds through relatives, friends, and private loans $[12,20,21]$, while family and friends are the embodiment of social networks. In general, the richer a family's social networks, the more friends and relatives it has, and the more likely it is to borrow. Among informal credits, due to the small rural area, the close association among the members of social networks, and the low cost of supervision, the moral hazard and adverse selection are effectively avoided [22]; there is considerable literature to suggest that social networks can alleviate the credit rationing problems caused by information asymmetry in rural areas [23]. To maintain household reputation under the rapid spread of public opinion word-of-mouth, social network members restrict their compliance with the loan contract to a certain extent, which plays an important role in the risk control of informal finance [22]. Thus, we propose Hypothesis 2.

Hypothesis 2. Social networks have a stronger positive impact on informal credit than formal credit.

With the continuous development of China's social economy, population mobility and nonagricultural employment have increased, and the implementation of family planning and late marriage policies made rural household size become smaller. With these, traditional family values have been affected and China's rural households are no longer small farmers and have begun to pay more attention to individual values and interests [24]. This leads them to change from survival rationality to social rationality, which brings about the subsequent change of the coverage and intensity of the rural family social networks [25]. In the traditional rural social relations, the rural household social networks are mainly based on the emotional relationship, which is strongly dependent on the family relationship and blood relationship with stability and relative nonselectivity [26]. With the development of the society, the social circle of rural households expanded beyond the blood relationship and instrumental social networks, which based on the professional or classmate relationship began to be established. According to their own purposes and needs, members of society will establish more externalized social relations and develop instrumental social networks based on mutual interests [27].

Emotional social networks are based on the family concept and the blood relationship and have strong stability and nonselectivity. What is more, violation of group rules and the likelihood of exclusion are lower in emotional social networks, which also means that institutional attributes of emotional social networks are not strong. Therefore, under emotional social networks, rural households are more likely to engage in informal credit behavior. On the one hand, because of China's strong family values and kinship ties, debtors are less likely to refuse loans from those in social networks. Moreover, the cost of borrowing is lower in an emotional society [28]; on the other hand, for formal financial credit, the role of the institution is stronger and the role of emotion is weaker [29]; most emotional social networks provide direct financial support rather than surety support. Previous studies have shown that even relatives and most families are reluctant to provide surety for others $[1,2,10,11]$. Therefore, we propose Hypothesis 3 .

Hypothesis 3. Emotional social networks have a stronger positive impact on informal credit behavior than on formal credit behavior.

As for instrumental social networks, the rural households are relatively more selective, and their maintenance is stronger [27]. Households pay more attention to get more information about employment, finance, and development from instrumental social networks; rural households can use this information more flexibly and scientifically to make better credit practices [28]. Compared to others, rural households with strong instrumental social networks can increase their access to credit by reducing information asymmetry [3], thus helping rural households improve their management and smooth risks and increase the income and the repayment ability of rural households. Based on this, we propose Hypothesis 4.

Hypothesis 4. Instrumental social networks have a stronger positive impact on formal credit behavior than on informal credit behavior.

\section{Materials and Methods}

3.1. Subject and Data Processing. Data for this article are from the China Household Finance Survey (CHFS) conducted by the Southwestern University of Finance and Economics, covering 29 provinces (cities, autonomous regions) except Tibet, Hongkong, Macao, Xinjiang, and Inner Mongolia. Using the proportional sampling method, 262 counties (cities, districts) were selected; then, four communities (villages and neighbourhood committees) were randomly selected from each county (cities, districts), and finally, 20-50 families were randomly selected from each community. CHFS adopts several measures to control errors such as nonsampling errors and investigates household credit, financial assets, and income at household, individual, and regional levels with high coverage and complete data on 
variables. Therefore, as far as the subject of this study is concerned, it has a good representation.

In this article, CHFS 2017 survey data were used as a source sample; the data were screened and cleared to determine the sample, whose process is as follows: firstly, the sample of urban household registration was excluded for this article mainly studies whether social networks affect the rural household credit behavior; secondly, minors and the elderly over 65 are often unable to borrow or have a weak willingness to borrow for reasons of trust, repayment ability, credit requirement restriction, etc. Considering the focus of this study, a sample between the ages of 16 and 60 years was chosen as the research object. Finally, the samples of "Unable to judge," "Missing," "Inapplicable," "Refusing to answer," and others in the variables of social networks credit behavior were eliminated, and 3,037 valid samples were left.

\subsection{Variable Selection and Measurement}

3.2.1. Household Credit Behavior. In this article, household credit behavior is divided into formal credit and informal credit. Formal credit refers to household credit to financial institutions such as banks, including agricultural, industrial, and commercial production and business and real estate, automobiles, education, and other loans. Informal credit refers to the borrowing or lending from relatives, friends, and nongovernmental credit organizations based on the production and management of agriculture, industry and commerce, real estate, automobile, education, etc. CHFS questionnaire on informal credit questions includes the following: in addition to bank or credit union loans, is your family still have informal credits not paid off due to industrial and commercial production? How much money was borrowed? Apart from bank or credit union loans, do you currently have outstanding informal loans from your family due to the purchase of your car or children's education? How much money was borrowed?.

3.2.2. Social Networks. Lin measured social networks with the heterogeneity of members in a social network, the most typical resources in the network, the roof of the network, and the net difference [30]. Gui and Huang obtained seven indicators of social networks based on data analysis, which are local social network, community trust, community belonging, voluntarism, community cohesion, reciprocity and general trust, and nonlocal social interaction [31]. According to previous literature, the indicators of social networks can be summarized as follows: community activity participation and community prestige; gift expenditure, gift income, gift exchange, and communication cost; the sum of cash and noncash income and expenditure on holidays and events; the number of relatives and friends visiting during the spring festival; the frequency to become the host through the "facesaving mechanism" principle; the number of relatives and friends who work in the government or in the city; the number of brothers and sisters and whether they are registered in this municipality; the four ways migrant workers looking for work (government organization, nongovernmental organization, introduction of relatives and friends, and spontaneous search) [27, 32, 33]. These measurements of social networks are novel and have taken the possible endogenetic problems into account, but some of them are too complicated to calculate; some of them are simply quantitative indicators that are not appropriate. Based on the available survey data and previous similar literature, this article measures social networks by giftmoney exchange, which is the sum of gift-money expenditure and gift-money income. In addition, according to the definition of emotional network and instrumental network, gift-money exchange with parents, children, and other relatives is regarded as emotional networks, while giftmoney exchange with classmates and friends is regarded as instrumental networks.

3.2.3. Control Variables. Referring to studies such as Attanasio et al. and Wan et al., this article selects the household head's gender, age, physical health, education, marital status, political outlook, risk attitude, work status, family size, household income, and the provinces as control variables. To maintain the characteristics of the data and avoid bias, we take the logarithm of the original data. The definition of variables and descriptive statistics are shown in Table 2.

In addition, the statistics on the specific behavior of rural household credit (Figure 2) show that in the survey samples, residents' funding needs are often met by informal credit, with a proportion of $82.4 \%$, and only $17.6 \%$ of households get funding from banks and other formal financial institutions. This is consistent with reality. Based on the data of fixed observation points in rural areas, we find that only less than $20 \%$ of rural households borrow from formal financial institutions. The reasons may be that for most rural households, they lack enough collateral or credit records; therefore, formal financial institutions usually cannot estimate the possibility of their default. As a result, information asymmetry leads to high transaction costs, and formal financial institutions are reluctant to lend to these households. At the same time, in informal credit behavior, $65.1 \%$ of households borrow funds and the leftover is informal lending behavior. This may be because, on the one hand, rural households have low income and usually need to borrow money to meet consumption expenditure or production activities; on the other hand, it may be because our statistics focus on borrowing activities rather than lending activities, so the data show that in informal credit behavior, borrowing activities are the main ones.

In terms of the amount of money spent on maintaining household social networks (Figure 3(a)), most households spend between 1,000 yuan and 5,000 yuan with a proportion of $45.99 \%$. In terms of the amount of money spent on maintaining emotional and instrumental networks (Figures 3(b) and 3(c)), most households spent between 1,000 and 5,000 yuan on maintaining emotional networks, while most spent between 5,000 and 10,000 yuan on instrumental networks. Overall, the latter is more expensive to maintain. 
TABle 2: Definition of variables and descriptive statistics.

\begin{tabular}{|c|c|c|c|c|c|}
\hline Variables & Definition & Mean & Standard deviation & Min & Max \\
\hline Social network & The sum of gift-money expenditure and income & 7.906 & 1.339 & 0 & 12.612 \\
\hline Emotional network & $\begin{array}{l}\text { The exchange of gift-money between parents, } \\
\text { children, and other relatives }\end{array}$ & 0.068 & 0.794 & 0 & 11.617 \\
\hline Instrumental network & $\begin{array}{l}\text { The exchange of gift-money between peers, } \\
\text { work partners and other friends }\end{array}$ & 5.937 & 3.602 & 0 & 12.612 \\
\hline Formal credit & $\begin{array}{l}\text { The actual amount borrowed from banks and } \\
\text { other financial institutions }\end{array}$ & 0.965 & 3.144 & 0 & 17.727 \\
\hline Informal credit & $\begin{array}{l}\text { The actual amount borrowed from relatives, } \\
\text { friends, and informal institutions }\end{array}$ & 4.171 & 5.104 & 0 & 16.705 \\
\hline Household credit behavior & $\begin{array}{c}\text { Whether to extend credit: yes }=1, \text { no }=0 \text {; } \\
\text { Credit amount: the sum of formal credit } \\
\text { and informal credit }\end{array}$ & 4.665 & 5.277 & 0 & 17.727 \\
\hline Gender & Male $=1$, female $=0$ & 0.471 & 0.499 & 0 & 1 \\
\hline Age & Survey year minus birth year & 37.845 & 12.901 & 16 & 60 \\
\hline Health & $\operatorname{Good}=1$, bad $=0$ & 0.843 & 0.363 & 0 & 1 \\
\hline Education & Level of education & 3.110 & 1.436 & 1 & 9 \\
\hline Marriage & Married $=1$, others $=0$ & 0.754 & 0.430 & 0 & 1 \\
\hline Job & Employed $=1$, others $=0$ & 0.688 & 0.463 & 0 & 1 \\
\hline Politics & Party of $C P C=1$, others $=0$ & 0.020 & 0.142 & 0 & 1 \\
\hline Risk attitude & Risk aversion $=0$, risk neutral $=1$, risk preference $=2$ & 0.416 & 0.676 & 0 & 2 \\
\hline Family size & Number of family members & 1.794 & 0.406 & 1 & 3 \\
\hline Family income & Total household income & 10.411 & 1.359 & 0 & 15.424 \\
\hline
\end{tabular}

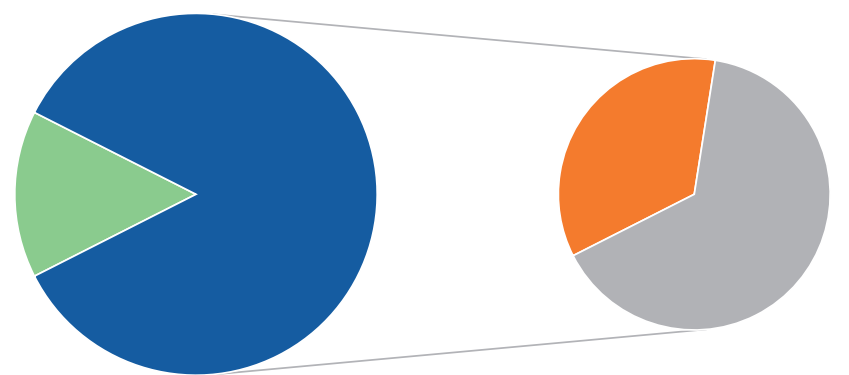

- Formal credit

- Informal lending

- Informal borrowing

FIGURE 2: Distribution of different types of rural household credit behavior.

\subsection{Common Method}

3.3.1. Probit Model. The probit model is used to analyze the effect of social networks on whether rural households participate in credit behavior. The model is set as follows:

$$
\operatorname{Prob}\left(y_{D}=1\right)=\alpha_{1} \text { social_network }+\beta_{1} X_{i}+\mu_{i},
$$

where $X_{i}$ is control variables, $\mu_{\mathrm{i}}$ is the residual, $\mu_{i} \sim N\left(0, \sigma^{2}\right)$, $y_{D}$ is the dumb variable of the credit behavior, $y_{D}=1$ indicates that households credit behavior occurs, and $y_{D}=0$ means no households credit behavior occurs.

\subsubsection{Panel Data Model}

$$
y_{i r}=\alpha_{1 i r} \text { social_network } k_{i r}+\beta_{1 i r} X_{i r}+\gamma_{r}+\mu_{i r} \text {. }
$$

$Y_{\text {ir }}$ denotes household credit behavior, including total credit scale, formal credit scale, and informal credit scale. $i$ represents households, $r$ represents the province, and $\gamma_{i r}$ is the fixed effect of provincial classification.

3.3.3. Two-Stage Least Squares. In addition, the variables of social networks may be endogenous, which may come from two aspects: on the one hand, households participate in formal credit or informal credit, which may lead to changes in social networks; for example, the increase in demand for family participation in formal and informal credit will spawn more exchange of gifts and social contacts, thus expanding its social network resources. On the other hand, social networks and household formal and informal credit practices and amounts may be influenced by factors, such as local cultural background and customs, which are not observable. Therefore, a key problem to be dealt with in this article is the endogenesis of social networks. After repeated tests, this article holds that communication cost can be used as an instrumental variable for it represents the level of communication with others and can subtly increase their own social network resources, while it has no close relationship with variables in residual. The model is as follows:

$$
\begin{aligned}
y_{i r} & =\alpha_{1 i r} \text { social_networkIV }{ }_{i r}+\beta_{1 i r} X_{i r}+\gamma_{r}+\mu_{i r}, \\
\text { social_networkIV }_{i r} & =\alpha_{2 i r} \text { social_network }_{i r}+\beta_{2 i r} X_{i r}+\gamma_{r}+\mu_{i r},
\end{aligned}
$$



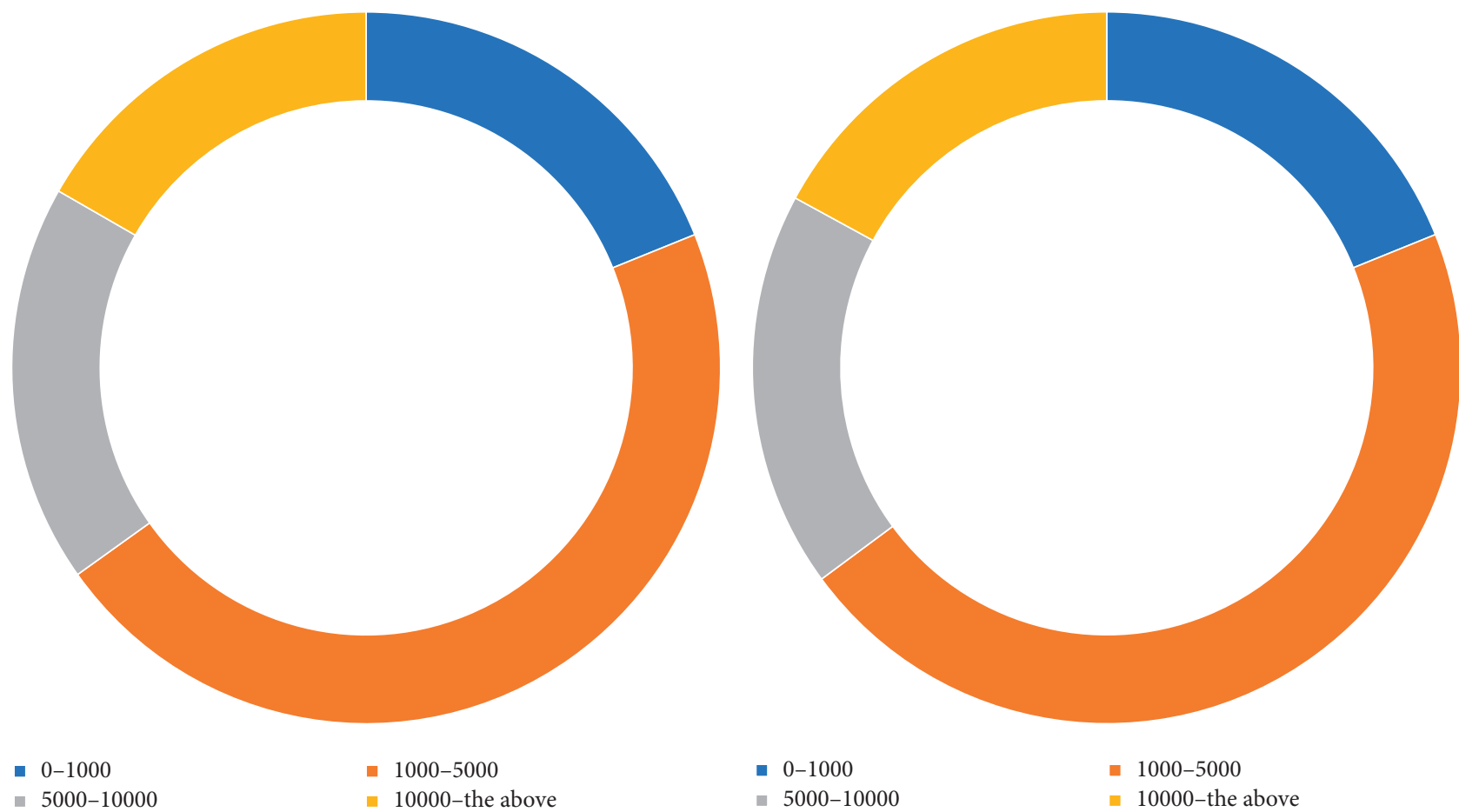

- 0-1000

- 5000-10000
-1000-5000

- 10000-the above
- 5000-10000

(a)

(b)

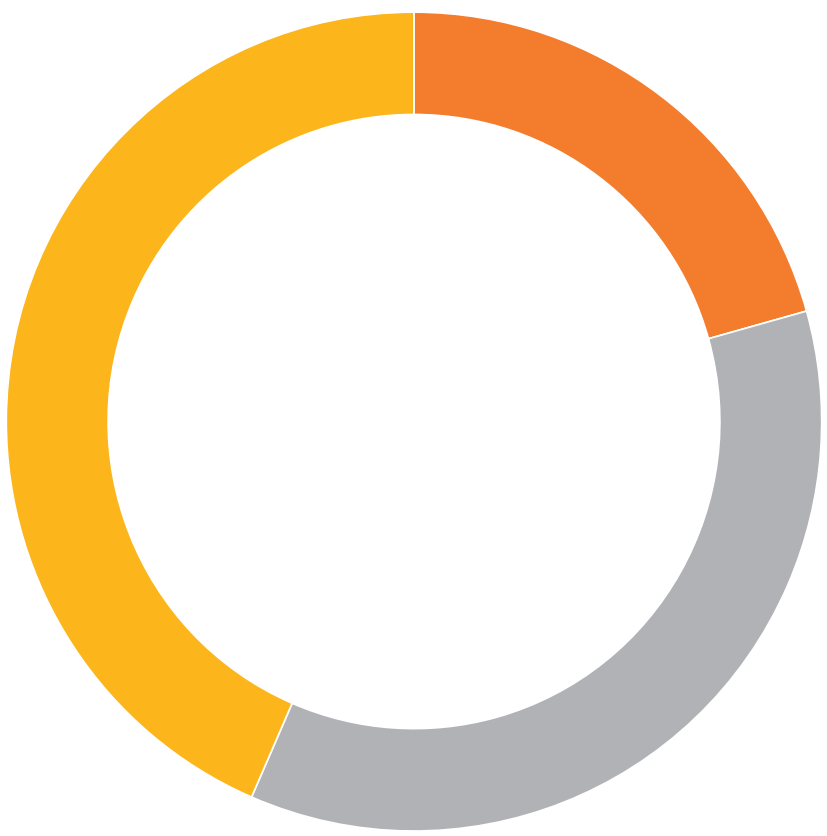
- $0-1000$
- 1000-5000
- 5000-10000
- 10000-the above

(c)

FIgURE 3: The money spent on maintaining social networks. (a) Social networks. (b) Emotional network. (c) Instrumental network.

where Social_networkIV is the instrumental variable of Social_network.

\section{Results and Discussion}

4.1. Main Results. The probit model is used to test the relationship between social networks empirically and whether rural households take credit or not (Table 3 (1)). The results show that when other conditions remain unchanged, for every $1 \%$ increase in rural household social network relationship maintenance expenditure, the probability of households choosing credit behavior increases by $0.489 \%$; that is, social network relationships do 
TABLE 3: Impact of social networks on rural household credit behavior.

\begin{tabular}{|c|c|c|c|}
\hline & $\begin{array}{c}\text { (1) } \\
\text { Whether credit or } \\
\text { not }\end{array}$ & $\begin{array}{c}\text { (2) } \\
\text { Credit scale }\end{array}$ & $\begin{array}{c}(3) \\
\text { Credit scale }\end{array}$ \\
\hline \multirow[t]{2}{*}{$\begin{array}{l}\text { Social } \\
\text { networks }\end{array}$} & $0.489^{* * *}$ & $0.596^{* * *}$ & $0.684^{* * *}$ \\
\hline & $(0.072)$ & $(0.075)$ & $(0.099)$ \\
\hline Education & $\begin{array}{c}-0.046^{*} \\
(0.019)\end{array}$ & $\begin{array}{c}0.085 \\
(0.078)\end{array}$ & $\begin{array}{c}-0.199^{*} \\
(0.101)\end{array}$ \\
\hline Job & $\begin{array}{c}0.093 \\
(0.053)\end{array}$ & $\begin{array}{l}0.465^{*} \\
(0.223)\end{array}$ & $\begin{array}{c}0.442 \\
(0.252)\end{array}$ \\
\hline Gender & $\begin{array}{c}0.086 \\
(0.047)\end{array}$ & $\begin{array}{c}0.200 \\
(0.199)\end{array}$ & $\begin{array}{l}0.460^{*} \\
(0.231)\end{array}$ \\
\hline Health & $\begin{array}{c}-0.355^{* * *} \\
(0.067)\end{array}$ & $\begin{array}{c}-0.280^{* * * *} \\
(0.028)\end{array}$ & $\begin{array}{c}-0.661^{* *} \\
(0.315)\end{array}$ \\
\hline Age & $\begin{array}{c}-0.015^{* * *} \\
(0.002)\end{array}$ & $\begin{array}{c}-0.045^{* * *} \\
(0.010)\end{array}$ & $\begin{array}{c}-0.075^{* * *} \\
(0.012)\end{array}$ \\
\hline Family size & $\begin{array}{c}0.091 \\
(0.057)\end{array}$ & $\begin{array}{c}0.307 \\
(0.249)\end{array}$ & $\begin{array}{l}0.558^{*} \\
(0.277)\end{array}$ \\
\hline Marriage & $\begin{array}{c}0.020 \\
(0.067)\end{array}$ & $\begin{array}{l}0.554^{*} \\
(0.273)\end{array}$ & $\begin{array}{c}0.141 \\
(0.325)\end{array}$ \\
\hline Politics & $\begin{array}{c}0.103 \\
(0.164)\end{array}$ & $\begin{array}{c}1.261 \\
(0.682)\end{array}$ & $\begin{array}{c}0.676 \\
(0.788)\end{array}$ \\
\hline Family income & $\begin{array}{c}-0.117^{* * *} \\
(0.027)\end{array}$ & $\begin{array}{c}0.063 \\
(0.081)\end{array}$ & $\begin{array}{c}-0.510^{* *} \\
(0.161)\end{array}$ \\
\hline Risk attitude & $\begin{array}{c}0.034 \\
(0.034)\end{array}$ & $\begin{array}{c}0.233 \\
(0.141)\end{array}$ & $\begin{array}{c}0.121 \\
(0.162)\end{array}$ \\
\hline Constant & $\begin{array}{c}-1.962^{* * *} \\
(0.391)\end{array}$ & $\begin{array}{c}0.564 \\
(1.119)\end{array}$ & $\begin{array}{c}-7.720^{* *} \\
(2.391)\end{array}$ \\
\hline$N$ & 3037 & 3037 & 3037 \\
\hline
\end{tabular}

Note: standard errors in parentheses ${ }^{*} p<0.05,{ }^{* *} p<0.01,{ }^{* * *} p<0.001$.

help promote household credit behavior. Meanwhile, from the empirical results of social networks on the scale of rural household credit (Table 3 (2)), social networks also have a significant positive impact on the scale of household credit. For every $1 \%$ increase in social network maintenance expenditure, the household credit scale increases by $0.596 \%$.

Due to the possible endogenous social network variables, 2SLS is used to estimate instrumental variable regression (Table 3 (3)). In the Durbin Wu Hausman endogeneity test, the D-Wu Hausman statistic is 3.782 , and it is significant at the level of $10 \%$, which indicates that there is endogeneity in the variable of social networks. The communication cost is selected as the instrumental variable, and the Wald F value is 60.616, which means the instrumental variable has passed the validity test. The results show that when communication fees are used as social network instrumental variables; for every $1 \%$ increase in communication fees, the scale of household credit increases by $0.684 \%$. In summary, Hypothesis 1 has been verified, and social networks have a significant positive impact on rural household credit behavior.

In addition to the main variables, most of the control variables also show good statistical characteristics. Educational experience has a significant negative impact on household credit behavior. Educational experience increases one level, the likelihood of households choosing to use credit increase by $4.6 \%$ and household credit scale by $19.9 \%$; health status, age, and total household income also have significant negative impacts. Compared with residents with good health, households with average or poor health are more likely to credit and borrow higher amounts. This may be due to the relatively less income of residents with average or poor health [23]. Their families need to pay a higher amount for health; the older the person is, the less likely it is to borrow and the smaller the amount of borrowing is, which may be because the older they are, the less they can work for the remaining years, and their repayment ability is limited or they may not be able to meet the credit conditions; the higher the total household income is, the less they will choose to borrow and the lower the borrowing amount is. This is in line with reality: under normal circumstances, when family income can cover family expenditures, there is no need for families to make additional borrowing.

\subsection{Results of Social Network on Formal Credit and Informal} Credit. As the characteristics and requirements of formal credit and informal credit are different, the influence of social networks on them may also be different. Therefore, this article makes an empirical test on the relationship between social networks and formal credit or informal credit; the results are in Table 4. Columns (1) and (2) are estimated by panel fixed effect, and columns (3) and (4) are estimated by 2 SLS.

The results of Table 4 (1) and (3) show that social networks have a significant positive impact on the formal credit behavior of rural households. The panel estimation results show that, under other unchanged conditions, for every $1 \%$ increase in social network maintenance expenditures, the amount of formal credit will increase by $0.173 \%$ (Table 4 (1)). The results of 2SLS (Table 4 (3)) are consistent with the panel fixed effect, which shows the coefficient is 0.980 . The coefficient of the former increases nearly five times of the latter, which means that the endogeneity of social networks is worth considering. Educational experience, marital status, and family income have a significant positive impact on the amount of formal family credit: for each level of education experience, the amount of household formal credit increases by $33 \%$. This may be because households with high academic qualifications are more likely to meet formal financial requirements [18]; compared to unmarried families, married families can obtain higher financial loans, and the amount is $52.9 \%$ higher than that of unmarried families. This may be because married families have more stable income and stronger repayment ability; for every $1 \%$ increase in family income, the credit amount increases by $0.132 \%$. This is also because families with higher income have stronger repayment ability and easier access to loans [17].

The results of Table 4 (2) and (4) show that social networks also have a significant positive impact on informal credit. Panel estimation shows that for every $1 \%$ increase in social networks maintenance spending, the amount of informal credit increases by $0.531 \%$ (Table 4 (2)). The results of 2SLS (Table 4 (4)) are consistent with the panel fixed effect, which shows the coefficient is 0.414 . The coefficient of the 
TABLE 4: Impact of social networks on formal and informal credit behavior.

\begin{tabular}{|c|c|c|c|c|}
\hline & $\begin{array}{c}\text { (1) } \\
\text { Formal credit }\end{array}$ & $\begin{array}{c}(2) \\
\text { Informal credit }\end{array}$ & $\begin{array}{c}(3) \\
\text { Formal credit }\end{array}$ & $\begin{array}{c}(4) \\
\text { Informal credit }\end{array}$ \\
\hline Social networks & $\begin{array}{c}0.173^{* * *} \\
(0.048)\end{array}$ & $\begin{array}{c}0.531^{* * *} \\
(0.072)\end{array}$ & $\begin{array}{l}0.980^{* *} \\
(0.298)\end{array}$ & $\begin{array}{c}0.414^{* * *} \\
(0.473)\end{array}$ \\
\hline Education & $\begin{array}{c}0.330^{* * * *} \\
(0.050)\end{array}$ & $\begin{array}{l}-0.107 \\
(0.075)\end{array}$ & $\begin{array}{c}0.243^{* * * *} \\
(0.060)\end{array}$ & $\begin{array}{c}-0.365^{* * *} \\
(0.096)\end{array}$ \\
\hline Job & $\begin{array}{l}-0.223 \\
(0.143)\end{array}$ & $\begin{array}{l}0.669^{* *} \\
(0.214)\end{array}$ & $\begin{array}{l}-0.226 \\
(0.151)\end{array}$ & $\begin{array}{l}0.623^{* *} \\
(0.239)\end{array}$ \\
\hline Gender & $\begin{array}{c}0.107 \\
(0.127)\end{array}$ & $\begin{array}{c}0.155 \\
(0.191)\end{array}$ & $\begin{array}{c}0.217 \\
(0.138)\end{array}$ & $\begin{array}{c}0.366 \\
(0.219)\end{array}$ \\
\hline Health & $\begin{array}{l}-0.120 \\
(0.180)\end{array}$ & $\begin{array}{c}-0.237^{* * *} \\
(0.027)\end{array}$ & $\begin{array}{l}-0.272 \\
(0.189)\end{array}$ & $\begin{array}{c}-0.555^{*} \\
(0.299)\end{array}$ \\
\hline Age & $\begin{array}{l}-0.004 \\
(0.007)\end{array}$ & $\begin{array}{c}-0.043^{* * *} \\
(0.010)\end{array}$ & $\begin{array}{l}-0.013 \\
(0.007)\end{array}$ & $\begin{array}{c}-0.070^{* * *} \\
(0.012)\end{array}$ \\
\hline Family size & $\begin{array}{c}0.081 \\
(0.159)\end{array}$ & $\begin{array}{c}0.444 \\
(0.239)\end{array}$ & $\begin{array}{c}0.149 \\
(0.165)\end{array}$ & $\begin{array}{l}0.670^{*} \\
(0.263)\end{array}$ \\
\hline Marriage & $\begin{array}{l}0.529^{* *} \\
(0.175)\end{array}$ & $\begin{array}{c}0.310 \\
(0.262)\end{array}$ & $\begin{array}{c}0.377 \\
(0.193)\end{array}$ & $\begin{array}{l}-0.051 \\
(0.308)\end{array}$ \\
\hline Politics & $\begin{array}{l}-0.278 \\
(0.438)\end{array}$ & $\begin{array}{l}1.329^{*} \\
(0.655)\end{array}$ & $\begin{array}{l}-0.608 \\
(0.471)\end{array}$ & $\begin{array}{c}0.786 \\
(0.748)\end{array}$ \\
\hline Family income & $\begin{array}{l}0.132^{*} \\
(0.052)\end{array}$ & $\begin{array}{l}-0.039 \\
(0.078)\end{array}$ & $\begin{array}{l}-0.085 \\
(0.096)\end{array}$ & $\begin{array}{c}-0.564^{* * *} \\
(0.153)\end{array}$ \\
\hline Risk attitude & $\begin{array}{l}-0.025 \\
(0.091)\end{array}$ & $\begin{array}{c}0.192 \\
(0.136)\end{array}$ & $\begin{array}{l}-0.078 \\
(0.096)\end{array}$ & $\begin{array}{c}0.099 \\
(0.153)\end{array}$ \\
\hline Constant & $\begin{array}{c}-2.816^{* * *} \\
(0.717)\end{array}$ & $\begin{array}{l}1.831 \\
(1.076)\end{array}$ & $\begin{array}{c}-6.169^{* * *} \\
(1.428)\end{array}$ & $\begin{array}{r}-5.556^{*} \\
(2.269)\end{array}$ \\
\hline$N$ & 3037 & 3037 & 3037 & 3037 \\
\hline
\end{tabular}

Note: standard errors in parentheses ${ }^{*} p<0.05,{ }^{* *} p<0.01,{ }^{* * *} p<0.001$.

former is close to the latter, which means the endogeneity of social networks in informal credit is not obvious. Work status, health status, and age also have significant impacts on the amount of informal credit: compared with nonworking residents, the amount of informal credit obtained by working residents is $66.9 \%$ higher. This is because working residents have income and a source of repayment [18]; the improvement of health status reduces the amount of informal credit. The amount of loans borrowed by residents with good health is $23.7 \%$ less than the amount borrowed by residents with average or poor health. This may be because residents in good conditions have more opportunities to find a job, and their medical expenses are less, so their loan amount needs are less [19]; the older the age, the smaller the amount of informal credit, and the amount of borrowing decreases by $4.3 \%$ for each year of increase. This may be because as residents get older, their ability to repay gradually decreases, so the number of loans borrowed decreases.

In addition, comparing the impact of social networks on formal credit and informal credit (Figure 4), it can be found that social networks have a stronger impact on informal credit no matter it is linear fitting (Figure 4(a)) or curve fitting (Figure 4(b)). Hypothesis 2 has been verified. This is consistent with the research of scholars such as He et al. [15] and Yang et al. [1]: on the one hand, since formal credit requires mortgage or guarantee, although social networks can be used as a kind of "hidden" guarantee and supervision mechanism; it is incompatible with practical material. There are still gaps in guarantees, and rural households may still be restricted by formal credit rationing and cannot get loans; on the other hand, plentiful social networks mean more relatives, friends, and closer contacts between social network members; this can effectively avoid moral hazard and adverse selection [3]. Moreover, the rapid spread of public opinion in social networks can also restrain debtors from complying with loan contracts [33]. Therefore, the enrichment of social networks can effectively strengthen rural informal credit.

\subsection{Results of Emotional Network and Instrumental Network} on Household Credit Behavior. In social networks, differences in connection strength between individuals form different types of networks, strong connections form emotional networks, and weak connections form instrumental networks. This section empirically examines the relationship between different types of networks and household credit behavior. The results are shown in Table 5 .

Columns (1) and (2) in the table are the influence of emotional networks and instrumental networks on the total household credit amount. The results show that emotional networks and instrumental networks have significant positive impacts on the amount of household credit with coefficients of 0.423 and 0.169 , respectively, indicating that with other unchanged conditions, each time emotional networks maintenance expenditure increases by $1 \%$, the credit amount increased by $0.423 \%$, and for every $1 \%$ increase in instrumental networks maintenance expenditure, the credit amount increased by $0.169 \%$. 


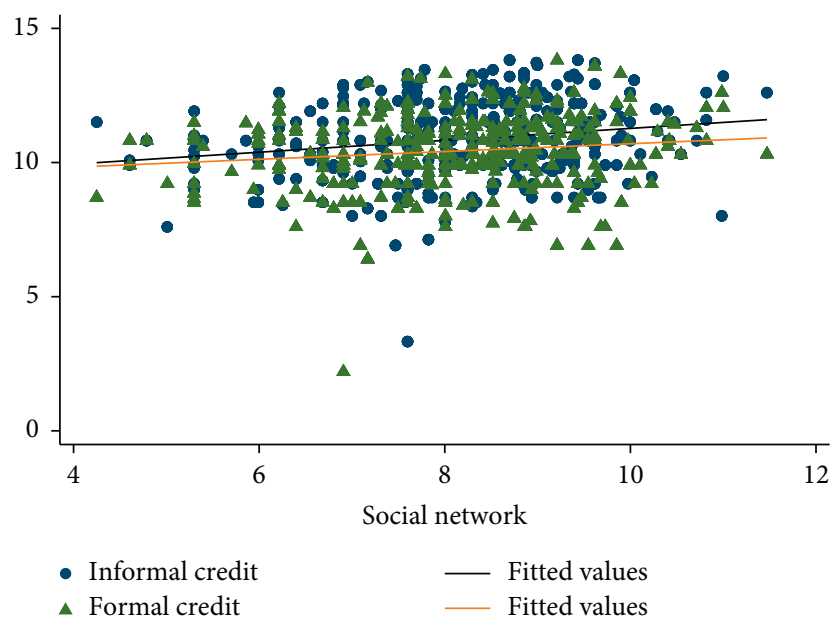

(a)

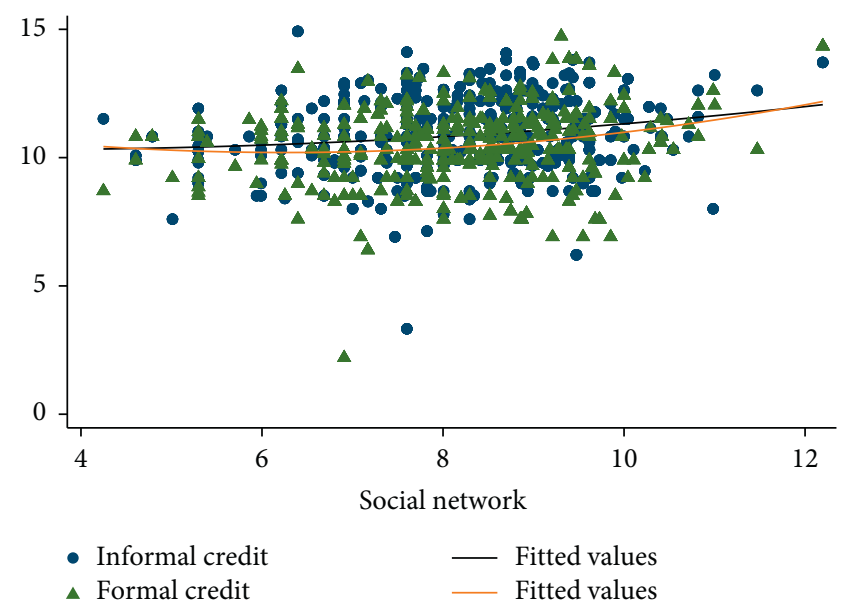

(b)

FIGURE 4: Slope graph of social networks on formal and informal credit behavior. (a) Linear fitting; (b) curve fitting.

TABLE 5: Impact of emotional and instrumental social networks on rural household credit behavior.

\begin{tabular}{|c|c|c|c|c|c|c|}
\hline & $\begin{array}{c}\text { (1) } \\
\text { Household credit }\end{array}$ & $\begin{array}{c}\text { (2) } \\
\text { Household credit }\end{array}$ & $\begin{array}{c}\text { (3) } \\
\text { Formal credit }\end{array}$ & $\begin{array}{c}(4) \\
\text { Formal credit }\end{array}$ & $\begin{array}{c}\text { (5) } \\
\text { Informal credit }\end{array}$ & $\begin{array}{c}(6) \\
\text { Informal credit }\end{array}$ \\
\hline Emotional networks & $\begin{array}{c}0.423^{* * *} \\
(0.095)\end{array}$ & & $\begin{array}{c}0.229^{* * *} \\
(0.059)\end{array}$ & & $\begin{array}{l}0.278^{* *} \\
(0.091)\end{array}$ & \\
\hline Instrumental networks & & $\begin{array}{c}0.169^{* * *} \\
(0.024)\end{array}$ & & $\begin{array}{c}0.061^{* * *} \\
(0.015)\end{array}$ & & $\begin{array}{c}0.142^{* * *} \\
(0.023)\end{array}$ \\
\hline Education & $\begin{array}{c}0.111 \\
(0.068)\end{array}$ & $\begin{array}{c}0.088 \\
(0.068)\end{array}$ & $\begin{array}{c}0.292^{* * *} \\
(0.042)\end{array}$ & $\begin{array}{c}0.287^{* * *} \\
(0.042)\end{array}$ & $\begin{array}{l}-0.058 \\
(0.065)\end{array}$ & $\begin{array}{l}-0.082 \\
(0.065)\end{array}$ \\
\hline Job & $\begin{array}{l}0.480^{*} \\
(0.195)\end{array}$ & $\begin{array}{l}0.460^{*} \\
(0.195)\end{array}$ & $\begin{array}{l}-0.115 \\
(0.120)\end{array}$ & $\begin{array}{l}-0.132 \\
(0.120)\end{array}$ & $\begin{array}{c}0.628^{* * *} \\
(0.187)\end{array}$ & $\begin{array}{l}0.615^{* *} \\
(0.187)\end{array}$ \\
\hline Gender & $\begin{array}{l}-0.062 \\
(0.174)\end{array}$ & $\begin{array}{r}-0.050 \\
(0.173)\end{array}$ & $\begin{array}{l}-0.053 \\
(0.107)\end{array}$ & $\begin{array}{l}-0.057 \\
(0.107)\end{array}$ & $\begin{array}{l}-0.005 \\
(0.167)\end{array}$ & $\begin{array}{c}0.009 \\
(0.166)\end{array}$ \\
\hline Health & $\begin{array}{c}-1.337^{* * *} \\
(0.244)\end{array}$ & $\begin{array}{c}-1.331^{* * *} \\
(0.243)\end{array}$ & $\begin{array}{l}-0.048 \\
(0.150)\end{array}$ & $\begin{array}{l}-0.047 \\
(0.150)\end{array}$ & $\begin{array}{c}-1.416^{* * *} \\
(0.234)\end{array}$ & $\begin{array}{c}-1.410^{* * *} \\
(0.233)\end{array}$ \\
\hline Age & $\begin{array}{c}-0.038^{* * *} \\
(0.009)\end{array}$ & $\begin{array}{c}-0.042^{* * *} \\
(0.009)\end{array}$ & $\begin{array}{c}0.003 \\
(0.005)\end{array}$ & $\begin{array}{c}0.001 \\
(0.005)\end{array}$ & $\begin{array}{c}-0.040^{* * *} \\
(0.009)\end{array}$ & $\begin{array}{c}-0.043^{* * *} \\
(0.009)\end{array}$ \\
\hline Family size & $\begin{array}{c}0.230 \\
(0.216)\end{array}$ & $\begin{array}{c}0.217 \\
(0.215)\end{array}$ & $\begin{array}{c}0.026 \\
(0.132)\end{array}$ & $\begin{array}{c}0.023 \\
(0.132)\end{array}$ & $\begin{array}{c}0.317 \\
(0.207)\end{array}$ & $\begin{array}{c}0.305 \\
(0.206)\end{array}$ \\
\hline Marriage & $\begin{array}{l}0.552^{*} \\
(0.233)\end{array}$ & $\begin{array}{l}0.534^{*} \\
(0.232)\end{array}$ & $\begin{array}{l}0.294^{*} \\
(0.143)\end{array}$ & $\begin{array}{l}0.311^{*} \\
(0.143)\end{array}$ & $\begin{array}{c}0.422 \\
(0.224)\end{array}$ & $\begin{array}{c}0.392 \\
(0.223)\end{array}$ \\
\hline Politics & $\begin{array}{l}1.446^{*} \\
(0.572)\end{array}$ & $\begin{array}{l}1.662^{* *} \\
(0.569)\end{array}$ & $\begin{array}{c}0.089 \\
(0.353)\end{array}$ & $\begin{array}{l}0.188 \\
(0.352)\end{array}$ & $\begin{array}{l}1.199^{*} \\
(0.549)\end{array}$ & $\begin{array}{l}1.358^{*} \\
(0.546)\end{array}$ \\
\hline Family income & $\begin{array}{l}0.170^{* *} \\
(0.065)\end{array}$ & $\begin{array}{c}0.119 \\
(0.066)\end{array}$ & $\begin{array}{c}0.185^{* * *} \\
(0.040)\end{array}$ & $\begin{array}{c}0.170^{* * * *} \\
(0.041)\end{array}$ & $\begin{array}{c}0.065 \\
(0.063)\end{array}$ & $\begin{array}{c}0.021 \\
(0.063)\end{array}$ \\
\hline Risk attitude & $\begin{array}{c}0.119 \\
(0.123)\end{array}$ & $\begin{array}{c}0.135 \\
(0.123)\end{array}$ & $\begin{array}{l}-0.033 \\
(0.076)\end{array}$ & $\begin{array}{l}-0.032 \\
(0.076)\end{array}$ & $\begin{array}{c}0.112 \\
(0.118)\end{array}$ & $\begin{array}{c}0.126 \\
(0.118)\end{array}$ \\
\hline Constant & $\begin{array}{c}3.859^{* * *} \\
(0.892)\end{array}$ & $\begin{array}{c}3.664^{* * *} \\
(0.889)\end{array}$ & $\begin{array}{c}-2.032^{* * * *} \\
(0.549)\end{array}$ & $\begin{array}{c}-2.139^{* * *} \\
(0.549)\end{array}$ & $\begin{array}{c}4.879^{* * *} \\
(0.856)\end{array}$ & $\begin{array}{c}4.737^{* * *} \\
(0.853)\end{array}$ \\
\hline$N$ & 3984 & 3974 & 4001 & 3991 & 3984 & 3974 \\
\hline
\end{tabular}

Note: standard errors in parentheses ${ }^{*} p<0.05,{ }^{* *} p<0.01,{ }^{* * *} p<0.001$.

Columns (3) and (4) are the influence of emotional networks and instrumental networks on the amount of household formal credit. The results show that emotional networks and instrumental networks also have significant positive impacts on the amount of household formal credit, with coefficients of 0.229 and 0.061 , respectively. Columns
(5) and (6) are the influence of emotional networks and instrumental networks on the amount of household informal credit. The results show that emotional networks and instrumental networks have significant positive impacts on the amount of household informal credit, with coefficients of 0.278 and 0.142 , respectively. 


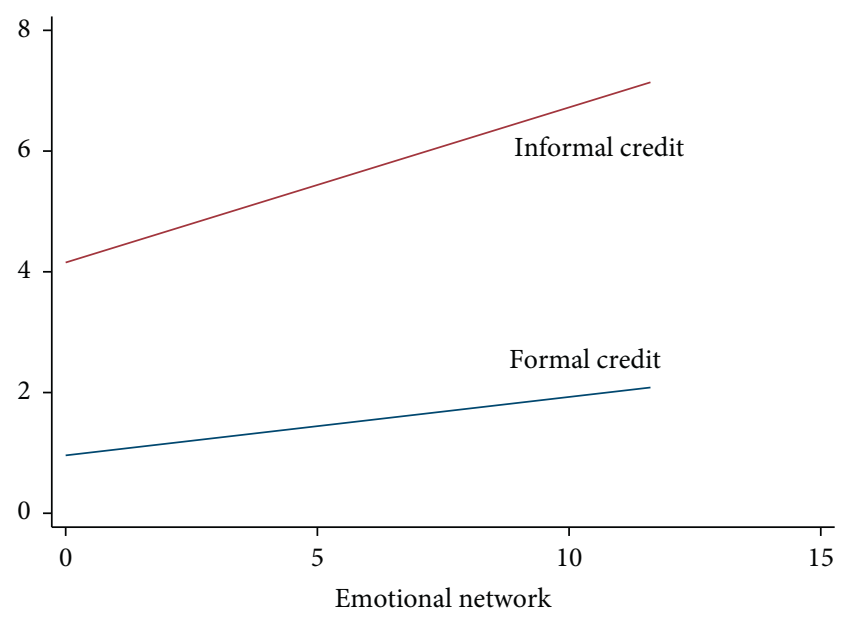

(a)

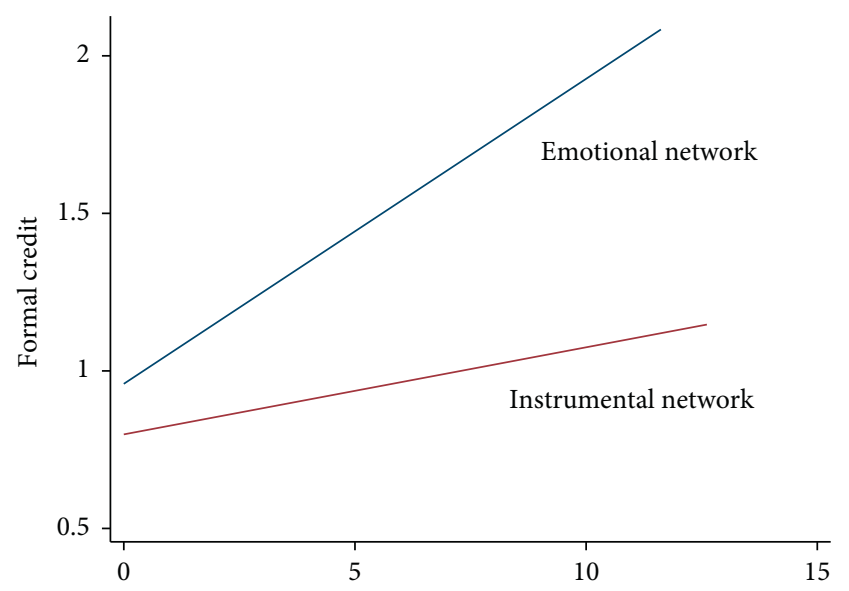

(c)

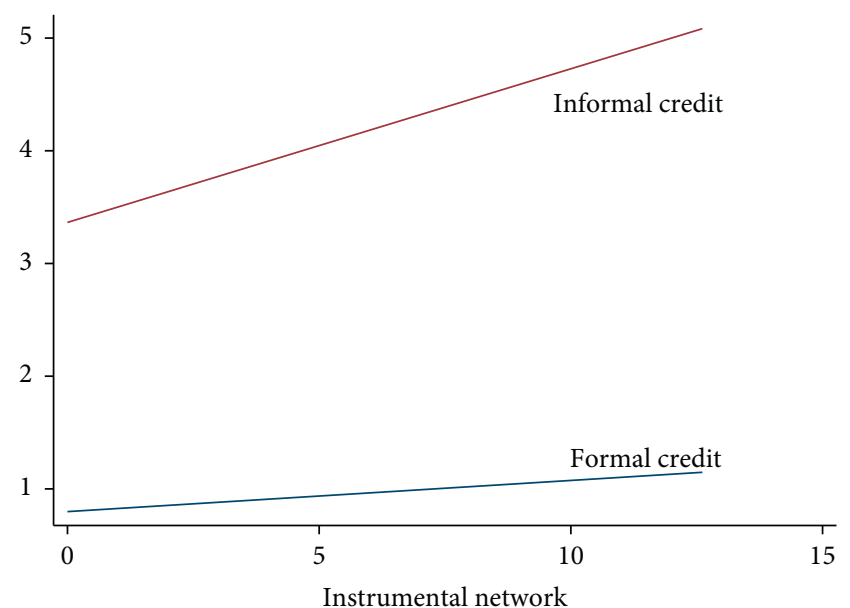

(b)

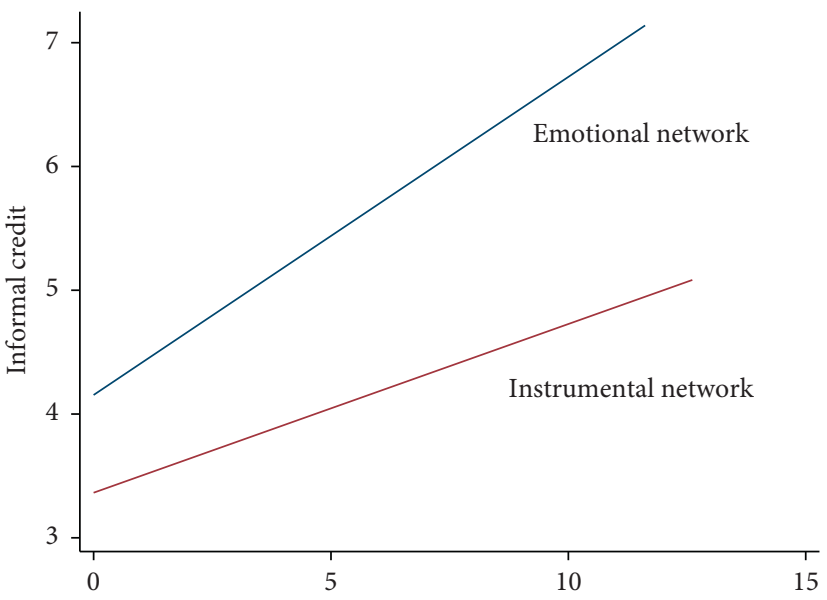

(d)

FIGURE 5: Slope graph of social networks effect on credit behavior. (a) Emotional networks and (b) instrumental networks effect on formal and informal credit. Emotional networks and instrumental networks effect on (c) formal and (d) informal credit.

Summarizing the impact of different types of networks on distinctive credit amounts (Figure 5), we find that whether it is an emotional network or an instrumental network, it has a significant positive impact on household credit behavior. Hypothesis 1 has been verified again. In addition, compared with formal credit behavior, emotional networks have a stronger positive impact on informal credit behavior (Figure 5(a)), Hypothesis 3 is verified; compared with formal credit, the positive influence of instrumental networks on informal credit behavior is stronger (Figure 5(b)), Hypothesis 4 is not verified. This may be because in social networks, households are more likely to borrow directly from individuals in the network and seldom make formal credit through individual relationships [20]. In addition, even if there are credit personnel from financial institutions in household instrumental networks, households must meet the formal credit conditions, which are not met by the invisible guarantee mechanism of social networks. Therefore, in general, the tool-based network has a stronger influence on informal credit. In addition, from Figures 5(c) and 5(d), we find that whether in formal credit or informal credit, the positive effect of emotional networks is stronger than that of instrumental networks.

\section{Conclusions}

This research discusses the impact of social networks on rural household credit behavior and explores the heterogeneity of the impact from differential networks and distinct credit behavior. The article first analyzes the influence of social networks on household credit behavior decisions based on game theory and further proposes hypotheses and conducts empirical tests. The results show that social networks can actively promote rural household choice of credit behavior and increase their credit amount. In addition, compared with formal household credit behavior, social networks have a stronger positive role in promoting informal credit behavior. This conclusion has also been confirmed in the influence of emotional networks and instrumental networks on household credit behavior. That is, both emotional and instrumental networks have a stronger influence on informal credit behavior than formal credit. At the same time, we also find that the positive effect of 
emotional networks is stronger than that of instrumental networks on either formal credit or informal credit. Therefore, we suggest that in the process of giving play to the role of rural financial credit, social networks should be actively used to transmit and supervise, especially to strengthen the establishment of emotional networks, which has an important practical effect on the development of formal financial credit and informal credit. Specifically, first, the implementation of finance credit should pay attention to the characteristics of the village acquaintance society in order to solve the problem of high transaction cost caused by information asymmetry. Secondly, when analyzing the effect of inclusive financial projects, the dynamic impact of external policies on the overall equilibrium should be considered for the factors that made mutual fund projects successful (such as the social network of villages) may change with the implementation of the projects, and then have a global impact on the policy effect. Third, by combining the formal system with the informal system, the government should create a more complete credit market environment and ease the credit constraints. Especially for farmers who lack collateral, it should fully consider the guarantee function of social networks with geographical and kinship relationship so as to solve the problem of loan difficulty in rural areas.

Although we have conducted an in-depth analysis of the relationhip between social networks and rural household credit behavior, this study also has some shortcomings. First, this study mainly uses cross-sectional sample data for analysis from an individual perspective, and it is difficult to obtain the dynamic process of variables in the individual development process. Secondly, this research only studies the direct relationship between social networks and household credit behaviors. The mechanism of how social networks affect household credit behaviors has not yet been explored. Future research could analyze the influence mechanism in detail and conduct empirical tests on it to understand more specifically the extent and path of the influence; finally, this study only considers rural samples and does not consider the influence of social networks on urban household credit behavior. Due to the dual development of rural households and urban households, their credit needs are different. Future research could also conduct heterogeneous research on the relationship between urban and rural family social networks and credit behavior.

\section{Data Availability}

The data used to support the findings of this study are available from the corresponding author upon request.

\section{Conflicts of Interest}

The authors declare that there are no conflicts of interest regarding the publication of this article.

\section{Acknowledgments}

This study was supported by the National Natural Science Foundation of China (71974157 and 72003113).

\section{References}

[1] R. D. Yang, B. K. Chen, and S. E. Zhu, "Research on Farmers' private credit demand behavior from the perspective of social network," Economic Research Journal, vol. 11, pp. 116-129, 2011.

[2] F. Hu and Y. Y. Chen, "Social networks and farmers' lending behavior: evidence from the CFPS," Financial Research, vol. 12, pp. 178-192, 2012.

[3] J. E. Stiglitz and A. Weiss, "Credit rationing in markets with imperfect information," American Economic Review, vol. 71, no. 3, pp. 393-410, 1981.

[4] B. Wellman, "Physical place and cyberplace: the rise of personalized networking," International Journal of Urban \& Regional Research, vol. 25, no. 2, pp. 227-252, 2015.

[5] J. E. Stiglitz, "Peer monitoring and credit markets," The World Bank Economic Review, vol. 4, no. 3, pp. 351-366, 1990.

[6] N. H. Nie, "Sociability, interpersonal relations, and the Internet: reconciling conflicting findings," American Behavioral Scientist, vol. 45, no. 3, pp. 420-435, 2001.

[7] D. S. Karlan, "Social connections and group banking," Economic Journal, vol. 117, no. 517, pp. 52-84, 2007.

[8] M. Shoji, K. Aoyagi, R. Kasahara, Y. Sawada, and M. Ueyama, "Social capital formation and credit access: evidence from Sri Lanka," World Development, vol. 40, no. 12, pp. 2522-2536, 2012.

[9] W. Zhou, "Brothers, household financial markets and savings rate in China," Journal of Development Economics, vol. 111, pp. 34-47, 2014.

[10] C. Zhou and H. J. Yue, "A study on Chinese farmers' family credit behavior from the perspective of social network," Journal of Xiangtan University (Philosophy and Social Science Edition), vol. 5, pp. 77-82, 2017.

[11] H. L. Qin, C. W. Li, and J. L. Wan, "Social capital, farmer heterogeneity and credit behavior-measurement analysis and empirical test based on CFPS data," Finance and Economy, vol. 1, pp. 33-40, 2019.

[12] X. Chen and S. Chen, "The quality of social capital and the availability of farmers' loans: an analysis based on professional reputation," Jiangxi Social Sciences, vol. 38, no. 5, pp. 218-226, 2018.

[13] G. Tenzin, K. Otsuka, and K. Natsuda, "Can social capital reduce proverty? a study of rural households in eastern Bhutan," Asian Economic Journal, vol. 29, no. 3, pp. 243-264, 2015.

[14] C. Okten, "Social networks and credit access in Indonesia," World Development, vol. 32, no. 7, pp. 1225-1246, 2004.

[15] G. W. He, J. He, and P. Guo, "Further discussion on farmers' credit demand and credit availability," Agricultural Economic Problems, vol. 2, pp. 38-49, 2018.

[16] Z. Y. Xu and H. Yang, "Analysis of farmers' credit behavior tendency and its influencing factors-based on the survey of 1664 farmers in 11 western provinces," China Soft Science Magazine, vol. 3, pp. 45-56, 2014.

[17] B. Wydick, H. K. Hayes, and S. H. Kempf, "Social networks, neighborhood effects, and credit access: evidence from rural Guatemala," World Development, vol. 39, no. 6, pp. 974-982, 2011.

[18] X. Gine, "Access to capital in rural Thailand: an estimated model of formal vs. informal credit," Journal of Development Economics, vol. 96, no. 1, pp. 16-29, 2011.

[19] P. D. Khoi, C. Gan, G. V. Nartea, and D. A. Cohen, "Formal and informal rural credit in the Mekong River Delta of 
Vietnam: interaction and accessibility," Journal of Asian Economics, vol. 26, pp. 1-13, 2013.

[20] F. Xiong, W. Shen, H. Chen, S. Pan, X. Wang, and Z. Yan, "Exploiting implicit influence from information propagation for social recommendation," IEEE Transactions on Cybernetics, vol. 50, no. 10, pp. 4186-4199, 2020.

[21] T. M. Chau, E. C. Gan, and B. D. Hu, "Credit constraints and their impact on farm household welfare: evidence from Vietnam's North Central Coast region," International Journal of Social Economics, vol. 43, no. 8, pp. 782-803, 2016.

[22] O. Attanasio, A. Barr, and J. C. Cardenas, "Risk pooling, risk preferences and social network," American Economic Journal: Applied Economics, vol. 4, no. 2, pp. 134-167, 2012.

[23] Y. Wang, M. J. Jinhong, and Z. Yuan, "Social network and credit market: evidence from China," Journal of Financial Research, vol. 412, no. 10, pp. 116-132, 2014.

[24] H. C. Xia, Z. X. Yan, and Z. Liang, "Impacts of social capital on farmers' credit behavior: cases of Zhangye city, Gannan Tibetan autonomous Prefecture and Linxia Hui autonomous Prefecture in Gansu province," Arid Land Geography, vol. 37, no. 4, pp. 831-837, 2014.

[25] R. Bathish, D. Best, and M. Savic, "Is it me or should my friends take the credit? The role of social networks and social identity in recovery from addiction," Journal of Applied Social Psychology, vol. 47, no. 1, pp. 126-141, 2017.

[26] J. Lin, B. Y. Wu, and Z. D. Li, "The efficient social networks in household credit: friendship or kinship?" Journal of Financial Research, vol. 427, no. 1, pp. 130-144, 2016.

[27] S. Wang, "Instrumental networking and social network building: how horizontal networking and upward networking create social capital," Acta Psychologica Sinica, vol. 49, no. 1, pp. 116-127, 2017.

[28] S. Roberts and R. Dunbar, "Communication in social networks: effects of kinship, network size, and emotional closeness," Personal Relationships, vol. 18, no. 3, pp. 31-45, 2011.

[29] F. Xiong, X. M. Wang, and S. R. Pan, "Social recommendation with evolutionary opinion dynamics," IEEE Transactions on Systems, Man, and Cybernetics: Systems, vol. 50, no. 10, pp. 3804-3816, 2020.

[30] N. Lin, "Social networks and status attainment," Annual Review of Sociology, vol. 25, no. 1, pp. 467-487, 1999.

[31] Y. Gui and R. G. Huang, "Measurement of community social capital: a study based on empirical data," Sociological Research, vol. 3, pp. 122-142, 2008.

[32] Y. Hu, F. Xiong, S. Pan, X. Xiong, L. Wang, and H. Chen, "Bayesian personalized ranking based on multiple-layer neighborhoods," Information Sciences, vol. 542, pp. 156-176, 2021.

[33] J. L. Wan, C. W. Li, and H. L. Qin, "Binary finance, social network and household lending-an empirical test based on repeated game model and CFPS data," Journal of Financial Development Research, vol. 7, pp. 42-49, 2018. 